\title{
Entrevista com Gláucio Ary Dillon Soares
}

Interview with Gláucio Ary Dillon Soares

Esta entrevista foi feita no Rio de Janeiro, nos dias 5 e 12 de maio de 2008, pelas editoras de Estudos Históricos Angela de Castro Gomes e Maria Celina D'Araujo

Gláucio Ary Dillon Soares é doutor em sociologia e um dos principais fundadores da moderna ciência social no Brasil. Embora venha de uma formação em direito, fez seus estudos de pós-graduação em sociologia, no exterior, e dedicou-se de forma pioneira ao estudo e aplicação de metodologias qualitativas e quantitativas em pesquisas sociais. Seu livro Sociedade e política no Brasil (São Paulo: Difel, 1973) é um marco nos trabalhos de sociologia eleitoral no país. Além disso, como professor convidado em diferentes países, dedicou-se ao estudo da política comparada, em especial partidos, eleições e desigualdades sociais. Mais recentemente adicionou às suas preocupações intelectuais a temática da violência. Esta entrevista ajuda a compreender a construção de um campo de co-

\footnotetext{
Angela de Castro Gomes (angela.gomes@fgv.br) e Maria Celina D’Araujo (maria.daraujo@fgv.br) são doutoras em ciência política e professoras titulares do CPDOC/FGV. Angela de Castro Gomes é também professora titular da UFF e coordenadora do Programa de Pós-Graduação em História, Política e Bens Culturais do CPDOC.
}

Estudos Históricos, Rio de Janeiro, vol. 21, nº 42, julho-dezembro de 2008, p. 323-349. 
nhecimento no Brasil e os cuidados metodológicos que foram sendo incorporados às ciências sociais brasileiras, marcadas em sua origem pelo ensaísmo.

Queremos conversar sobre sua contribuição para o estudo dos partidos políticos no Brasil. Mas antes gostaríamos que nos falasse sobre sua formação, para entendermos como você chegou a esse tema. Vamos começar pela graduação?

- Tropecei no direito, não escolhi. Naquele tempo não havia muitas opções. Um monte de carreiras existentes hoje não existia na época. Minha mãe era professora primária, meu pai tinha algum secundário e fazia trabalhos de contadoria. Não poderia pedir deles que me dessem orientação, informações - coisa que pouquíssimos pais naquele momento tinham -, e então fiz o vestibular para direito. Era o mais fácil, o menos custoso. Até que em determinado momento li no Diário de Notícias ou no Correio da Manhã que havia um curso de russo na PUC. Eu era então uma espécie de esquerda indecisa: não sabia se era realmente esquerda, se não era. Lia alguma coisa de marxismo, não muito, e queria aprender russo. Evidentemente, se eu fosse para um instituto de amizade Brasil-União Soviética, teria outra ficha no Dops, mais antiga que aquela que nós temos. Que melhor oportunidade do que um curso de russo dado na PUC, uma universidade católica, conservadora? Fui para lá.

Onde vocêfez seu curso de direito?

- Fui da primeira turma da Faculdade de Direito Cândido Mendes, em 1953. Éramos trinta e poucos, mas muitos caíram pelo caminho. Eu tinha sido um excelente estudante no primário, mas fui um total vagabundo no clássico, que fiz no Andrews. Era uma escola muito boa e cara para aquilo que meus pais podiam, mas não aproveitei o que poderia. Nem me preparei para o vestibular. Ainda assim passei, acho que em sétimo lugar. Tive aulas com o próprio Cândido Mendes, tive uma importante aula de direito constitucional com o depois ministro do Supremo e também presidente da Câmara dos Deputados, Célio Borja, tive um bom professor de direito civil chamado Cavalcanti, mas de novo aproveitei pouco. Um professor com quem encaixei bem foi o de filosofia do direito, Cristóvão Breyner.

Quando fui estudar russo na PUC, descobri que russo era parte de um programa de estudos de sociologia e política. ${ }^{1}$ Então, também tropecei na sociologia e na política. E, já que estava pagando pelo curso, resolvi assistir às aulas. Em questão de dias me apaixonei pela sociologia e também pela empiria. Um mês depois já era um convertido. Quem foi muito influente nesse campo foi o Padre Ávila, em parte por estarmos num momento em que ele oferecia uma perspectiva que eu até então não conhecia, e em parte porque era uma pessoa simpática. Eu adorava a PUC e me meti na política estudantil. Criei um centro acadêmi- 
co chamado Roquete Pinto, do qual fui presidente. Não entrei na política da UNE, mas me percebia como uma espécie de representante dos alunos, não só para pedir coisas etc., como também para estimular debates, atividades e cursos paralelos.

Até então, nem sociologia, nem ciência política eram disciplinas autônomas. Eram capítulos do direito. Havia na PUC um professor que ensinava ciência política, havia feito uma maîtrise na França ou na Bélgica, mas era essencialmente um advogado. Lembro que também era professor lá Celestino Sá Freire Basílio, um civilista. Havia um padre Mravak que ensinava uma psicologia social mais moderna, no sentido de mais distante do direito e mais próxima do que a sociologia é hoje. Havia também um professor de sociologia chamado Geraldo Semenzato, que vinha da Escola de Sociologia e Política de São Paulo. ${ }^{2}$

O curso de sociologia e política da PUC teve muito mais impacto sobre mim do que o de direito. As próprias instalações da PUC eram muito melhores, e os professores tinham mais contato com os alunos. Ou porque não os busquei, ou porque não vi porta aberta, o contato entre professores e alunos na Cândido Mendes era mínimo. Em todo caso, terminei direito e fui orador da turma, junto com outro colega.

\section{Você lia muito quando estudante?}

- Sim. Minha carreira como intelectual começou na PUC, com vinte e poucos anos. E quanto mais eu lia, mais gostava. Comecei também a ver a diferenciação entre os textos. Alguns me cansavam, porque eram extremamente teóricos. Eu queria saber se aquilo dali era verdade, batia com a realidade, mas não havia muita gente preocupada com isso. Uma ocasião fiz uma visita a Minas, onde entrei em contato com o pré-programa do Júlio Barbosa, ${ }^{3}$ e fiquei entusiasmado. Havia bons alunos. Depois fui até São Paulo, conversei com Fernando Henrique, que já era professor, ${ }^{4}$ e outras pessoas. No Rio de Janeiro, não me lembro exatamente do que existia. Sei também que assisti na PUC a duas palestras que tiveram impacto sobre mim. Uma foi do Maurice Duverger. Eu disse: "Ah, gosto do que esse cara faz", e fui ler o livro dele, Les partis politiques. A outra foi do Charles Wagley, que, numa universidade católica, na década de 50, disse o seguinte: "Pode demorar, mas o divórcio vai chegar aqui, como está chegando a todas as partes do mundo". Percebi então que doutrina era uma coisa, cultura em transformação era outra. Ou seja, percebi a possibilidade de descompasso entre a doutrina das instituições e a mudança cultural. Isso gerou muita minhoca na minha cabeça. Sempre que aparece algo novo, acho que tenho de ir lá estudar, e sofro. Contrariamente ao que alguns acham, gosto da empiria mas não sou um estatístico, sou muito mais um usuário da estatística. Agora, tenho os meus consultores. É bom ter dois filhos econometristas, porque, quando a barra pesa, vou lá pedir ajuda. E é grátis... 


\section{Você chegou a se formar também em sociologia?}

- Não. Quando terminei direito, ganhei uma bolsa para fazer o mestrado em direito comparado nos Estados Unidos. Discuti com o Padre Ávila, se devia ficar e terminar sociologia, ou ir. Ele disse: "Acho que você deve ir. É um universo diferente, e você vai aprender muito". Bolsas então eram muito escassas, não havia programa de bolsas de pós-graduação como há hoje, de Capes, CNPq etc. Em 1958 eu já estava nos Estados Unidos.

\section{Como você obteve sua bolsa para os Estados Unidos?}

- Foi uma candidatura em concurso. Era uma bolsa da Fundação Rockefeller. Fui para a Universidade de Tulane, em Nova Orleans, recebia US\$132,00 por mês e mal conseguia viver numa pensão. Era um programa de mestrado feito para durar um ano ou um ano e pouco, com tese, e se a Universidade de Tulane não fosse uma instituição muito flexível eu não poderia ter feito o que fiz, que foi essencialmente estudar sociologia e ciência política. Pouca gente sabe, mas minha tese de mestrado em direito foi sobre Georges Gurvitch. Nome da época, que depois sumiu. Meu orientador chamava-se Mitchell Franklin. Era uma pessoa interessante, $\mathrm{o}$ "radical da universidade". Morava em um bairro negro e era comunista. Isso, nos Estados Unidos de 1958, e no Sul...

Aqui entra o que era Nova Orleans, o que foi muito importante, deixou marca. A Universidade de Tulane era segregada. Praticamente todas as universidades do Sul dos Estados Unidos o eram, a região era fortemente segregacionista. Sintomas e sinais estavam nas ruas. Havia coisas incríveis, como você vir andando pela calçada, e uma pessoa negra vir andando em sentido oposto; essa pessoa descia da calçada, ia para a rua para dar passagem. Nos ônibus e nos bondes, havia lugares reservados para brancos e lugares reservados para negros. Se casualmente uma pessoa negra sentasse do lado de uma branca, era freqüente que a pessoa branca se levantasse para revelar o seu desgosto com aquilo. Por que é importante ver isso? Porque em 2008, 50 anos depois, você vê um negro com chance de ser presidente dos Estados Unidos. Acho que aquele país, nesse sentido, tem muito do que se orgulhar, porque passar de um momento em que os banheiros eram segregados, as igrejas eram segregadas, a universidade não aceitava negros, para o que está acontecendo hoje, não é pouca coisa.

Essa experiência de certa maneira veio convergir com uma coisa que você levantou, que é o seu gosto pela sociologia, e mais, pela empiria, pelo campo. De certa forma você estava num campo, não é?

- Claro. Minha visão não é que a empiria se resume a dados quantitativos, tirados de censos ou de surveys. Empiria é você de alguma maneira entrar em contato com a realidade, é algo que está em oposição a racionalismo. Na origem, racionalismo é você acreditar que, pelo raciocínio, chega à verdade. Não à verda- 
de de tipo teológico, mas a uma explicação da realidade, sem precisar de mais nada. Esse racionalismo se desenvolveu a partir, sobretudo, da idéia das distorções da percepção. "Para não sermos enganados pelos nossos olhos, que vêem mal, viremos todos cegos, e através do raciocínio e da razão chegaremos à realidade e à explicação." Eu me batia muito contra isso, achava um absurdo.

Tive como professor, em Tulane, um sociólogo chamado Leonard Reissmann que escreveu um livro sobre estratificação, classes. Era um assunto que me fascinava. Por quê? Porque classe era uma categoria fundamental no pensamento marxista, mas ele tinha outra concepção, estudava classe empiricamente. Eu estava certamente cansado da postura de pessoas que não pesquisavam e simplesmente ficavam naquele achismo, chutando. Chute com erudição é igual à verdade? Isso me incomodava. Tive também algumas palestras com Kalman Silvert, que foi muito influente aqui no Brasil, porque idealizou o programa de bolsas em ciência política da Fundação Ford, que foi o programa que mudou a ciência política no Brasil. O Iuperj ${ }^{5}$ de uma certa época foi todo formado por esse programa.

Ainda em Tulane, o contato com outros latino-americanos estimulou meu pensamento a respeito da América Latina. Na minha turma também tive contato com alguns europeus, e perdi qualquer reverência que pudesse ter em relação a eles e aos americanos. Foi muito bom, sabe? Acho que no Brasil, e no resto da América Latina, muitas pessoas têm, sem admitir, uma atitude não só eurocên trica, no sentido de que pensam em categorias derivadas da experiência européia, mas uma atitude valorativa muito positiva em relação à Europa. Isso em mim morreu, e morreu agressivamente, quando um alemão que se proclamava socialista, mas era racista, me pediu cola durante os exames. Respondi com uma expressão grosseira.

Enfim, tive um professor em ciência política, chamado Kenneth Vines, que no seu curso mostrou dados do estado de Louisiana a respeito da percentagem de católicos e do impacto disso sobre a votação. A sociologia política aí se combinou com o interesse por questões religiosas, e continuou me marcando, certamente em um nível bem mais alto do que outros interesses que eu poderia ter tido no Brasil. Por tudo isso, ao se aproximar o fim desse período em Tulane, eu estava convicto da necessidade de pesquisar, e da necessidade de ser interdisciplinar. Essa história de separar sociologia aqui, ciência política ali e história acolá, para mim, era absurda. Mas aí me dei conta de que eu não sabia pesquisar. Como é que se faz isso? Essa percepção me levou a ampliar minha permanência nos Estados Unidos.

E como você conseguiu prorrogar sua estada?

- Minha bolsa terminou, mas busquei e encontrei vários centros de pesquisa, entre eles o National Opinion Research Center, NORC, em Chicago. 
Escrevi para lá, e eles me contrataram para todas as tarefas imagináveis dentro de projetos de pesquisa: perfurar cartões - usavam-se então cartões IBM -, fazer entrevistas a 10 ou $15^{\circ} \mathrm{C}$ abaixo de zero, verificar questionários etc. E aí outro conjunto de pessoas influiu sobre a minha vida. Uma delas foi Elihu Katz, que estava interessado em questões de família, religião etc. A pesquisa dele incluía coisas sobre aborto, e quase fui morto por causa disso. Literalmente. Fui corrido de uma comunidade italiana porque fiz perguntas sobre o assunto. Foi então que me dei conta de que a gente tem que tomar muito cuidado com o que pergunta...

Devido a uma sobrevalorização do meu conhecimento idiomático, me puseram para entrevistar imigrantes italianos, mexicanos etc. Até que aí me dei bem: aprendi italiano entrevistando em uma língua que eu deveria saber. Mas um dia me puseram para entrevistar uma russa. Eu disse: "Mas gente, eu não falo russo!” Eles: “Mas você estudou russo!” Eu: “Não! Está no meu currículo, mas é um erro!" Para fazer a entrevista precisei de tradutor, claro. Era uma senhora de 90 e poucos anos, que tinha nascido em Irkutsk, na Sibéria, migrado para a China, trabalhado em tudo que pôde, limpando chão etc., e que vivia em Chicago com 10 dólares por mês... Fiz aquilo que nenhum pesquisador deve fazer: na segunda vez em que fui entrevistá-la, fiz um monte de compras no supermercado e levei para ela. Tecnicamente um faux pas, erradíssimo, mas, puxa, como eu ia deixar aquela mulher daquele jeito, sem saber se ela comia ou não? Ela dizia que o marido da filha estava cansado de lhe dar aqueles 10 dólares... A história dessa mulher era fascinante. E ficou em mim a idéia, que desenvolvi depois, de colher histórias de vida, acompanhar as pessoas.

Naquele período, como não dava para viver com o que eu recebia pelo trabalho de pesquisador, também trabalhei de garçom, de bartender, de tudo. Me dei muito bem como garçom, porque eu trabalhava no clube da Universidade de Chicago, que se chamava Quadrangle Club, e decidi usar truques. Quando via algum professor que chegava querendo se mostrar - é muito fácil perceber isso -, perguntava: "O lugar de sempre, senhor?” Pronto! Ali já tinha um dólar na gorjeta... Também aprendi como o mundo acadêmico pode ser mesquinho, como podem te tratar mal. Uma coisa que ficou muito clara para mim é que se algum dia eu dirigisse um serviço de espionagem em algum lugar do mundo, meus espiões iam ser garçons, além, claro, de taxistas ou empregadas domésticas. Por quê? Porque o garçom não existe. O sujeito fala qualquer coisa com o garçom do lado, porque ele não existe, é invisível.

Essa segunda experiência nos Estados Unidos também deve ter sido muito rica, na medida em que lhe permitiu desempenhar várias atividades no interior de uma pesquisa.

- Claro. Aprendi a fazer survey, a desenhar uma pesquisa, porque o Elihu Katz discutiu o projeto com os pesquisadores, nos ensinou como chegar lá. Ain- 
da tive outra pessoa que foi muito influente: Duncan MacRae. Ele gostou de algumas discussões que tivemos a respeito da votação obtida pelo Partido Nazista, NSDAP, em 1932 na Alemanha. Às vezes, frases e atitudes solitárias influenciam uma vida inteira. Eu tinha que fazer uma amostragem das comunidades menores para relacionar voto com nível educacional e perguntei: "Mas para que fazer amostragem?" Ele disse: "Isso aí são centenas de observações, não são dezenas de milhares. Então, vai e faz! Passa aí uma semana fazendo e codifica o universo". Outra coisa que ele me disse e também marcou foi: "Quando você publicar, não coloque que é aluno, porque vão discriminá-lo, e acho isso um absurdo. Alunos podem publicar". Nunca me esqueci disso, passou a ser parte da minha agenda. Aprendi muito com ele, inclusive usei um índice dele de concentração de votos no primeiro ou segundo trabalho que fiz no Brasil depois de voltar.

\section{Quanto tempo você ficou em Chicago?}

- Seis, sete meses. Na verdade, ampliei um pouco a estada, porque estava absolutamente apaixonado por uma americana descendente de italianos - e aí sim aprendi italiano... Mas como eu não podia ficar mais, por conta do visto limitado, resolvi voltar. E voltei via Cuba. Por quê? Porque estava começando o regime de Fidel Castro. Um ano e pouco antes ele tinha tomado o poder. No caminho passei por Miami, onde encontrei estudantes que tinham sido minhas colegas em Tulane e me deram indicações de familiares em Cuba. Chegando a Cuba não fiquei muito tempo, menos de um mês -, me meti numa família e vi que a vida familiar era surpreendentemente parecida com a do Brasil. A música também era muito parecida - muitos anos depois descobri que isso tinha a ver com a origem comum ioruba. Naquele tempo não aprendi nada a respeito de Santeria, mas se tivesse aprendido teria visto que os nomes são os mesmos. Afinal voltei para o Brasil, inteiramente diferente do que fui, mas dentro da mesma linha. Queria fazer pesquisa, queria aprender, e já tinha aprendido alguma coisa - o bastante para saber que ainda faltava muito.

\section{O que você fez ao voltar para o Brasil?}

- Comecei a trabalhar na Fundação Getulio Vargas, no Instituto de Direito Público e Ciência Política, com Temístocles Cavalcanti, e também fui dar aulas na PUC. Lembro que na primeira turma em que ensinei estava Miriam Limoeiro. Naquele primeiro momento tive realmente alunos muito bons. Estudaram na PUC Otávio Velho, Alexandre Barros, depois Celina Vargas, Wellington Moreira Franco... Foi uma gente que depois marcou. Uns foram meus alunos, outros não. Na Fundação, fiquei tentando organizar a Revista de Direito Público e Ciência Política. Achei que podia fazer uma revista modernosa, mas Temístocles 
não quis deixá-la sob minha responsabilidade. Aí vieram as eleições. Isso mudou minha vida outra vez.

\section{Eram as eleições de 1960?}

- Eram. Lacerda candidato a governador da Guanabara, Lott e Jânio disputando a presidência da República. Na época, já se faziam aqui pesquisas eleitorais. Chamavam-se "prévias" e eram incrivelmente mal feitas. Pegava-se 50 pessoas e dizia-se: $80 \%$ vão votar em Carlos Lacerda. Eu olhava aquilo e via que todas as pessoas que tinham respondido eram de classe média. Era evidente. $\mathrm{Li}$ então que o Correio da Manhã ia fazer uma prévia, botei meu melhor - e único terno e fui lá conversar. Quem estava encarregado do assunto era - hoje eu diria um garoto, mas àquela altura era um senhor que devia ter uns 35 ou 40 anos. Eu disse: "Vocês vão dar com os burros n'água nessa pesquisa..." Ele: "Ah, mas nós vamos sair por aí, vamos entrevistar não sei quantas pessoas". Eu: "Não, é preciso saber se você tem uma amostra dos eleitores. Os eleitores não vão cair na sua amostra aleatoriamente". Aí o cara ficou impressionado. Naquele momento mesmo eu disse: "Olha, eu faço uma pesquisa de graça pra vocês. Depois vocês me dão os dados coletados e faço um carnaval com eles, escrevo artigos etc." Nós conseguimos acesso, que hoje eu sei que era ilegal, mas na época não sabia, aos registros do Tribunal Regional Eleitoral. Havia gavetas, mas não havia uma listagem. Então usei um substitutivo, que foi uma amostragem espacial-aleatória-sistemática. Ou seja, você mede o tamanho das gavetas, torce para que elas estejam compactadas de maneira igual e depois divide o total pelo número de entrevistas que você vai fazer. E, claro, pega também um grupo para reposição, ou seja, um número de pessoas para entrevistar caso se percam algumas entrevistas da primeira amostra. Depois apareceram alguns vieses nessa amostra, e nós ponderamos por zona eleitoral. E o resultado foi na cabeça. Pim!

Nas entrevistas, introduzi perguntas a respeito de identificação de classe, de raça - ou seja, meu interesse em classe e política voltou nessa pesquisa. E aconteceram coisas interessantes. Primeiro, na minha ingenuidade, eu não percebia que as entrevistas podem ser fraudadas. Eu estava copiando um sistema existente em Chicago, que é você refazer $5 \%$ das entrevistas de cada entrevistador. Nós tínhamos uma amostra grande, de duas mil e tantas pessoas. E aí descobrimos que um cara tinha fraudado todas as entrevistas dele: duzentas e poucas. Era, de longe, quem tinha feito mais entrevistas. Tivemos que refazê-las, e eu disse para mim: se alguém fraudou na totalidade, é muito fácil fraudar uma parte. Então refizemos as entrevistas todas da amostra, e isso começou a me preocupar, porque estávamos chegando perto da eleição, e os dados que registramos em momentos diferentes mostravam mudanças no quadro eleitoral. Ou seja, havia candidatos ganhando votos e candidatos perdendo votos. Nesse momento, recebo uma carta ameaçadora de alguém que era chamado de "O homem da capa preta". 


\section{Tenório Cavalcanti!}

Tenório Cavalcanti. Fiquei tremendo na base: "Ih, se ele é conhecido por andar com uma metralhadora, eu não vou ficar aqui, não". E me mandei para Brasília, que estava sendo construída... Estive lá muito rapidamente, porque fiquei com medo de levar um tiro do Tenório Cavalcanti, e voltei depois das eleições.

Essa pesquisa gerou meus primeiros artigos baseados em dados que eu mesmo coletei. Eu já tinha escrito um artigo, chamado "Urbanização e dispersão eleitoral", com Amélia Maria Carvalho Noronha, no qual mostrava que os municípios mais urbanizados eram os que tinham mais partidos e uma distribuição da votação mais eqüitativa entre os partidos. Meu primeiro artiguinho empírico, com dados agregados, foi esse, publicado na Revista de Direito Público e Ciência Política da FGV. ${ }^{6}$ Depois usei os dados das eleições para publicar dois artigos na Sintese Econômica, Política e Social, da PUC. Escrevi outros artigos a partir daí, inclusive um sobre classes sociais, strata sociais e consciência de classe, de que Oracy Nogueira gostou bastante. E resolvemos criar um programa de estudos de metodologia dentro do Instituto de Direito Público e Ciência Política da Fundação. Contratei estatísticos, e demos cursos, não sobre estatística, mas sobre métodos. Tínhamos uns 8,10 ou 15 alunos, mais ou menos.

Até então eu vivia com meus pais, porque a grana não dava. No momento em que saiu essa pesquisa de campo e o resultado bateu, ao passo que os resultados das primeiras empresas de opinião pública que se aventuraram não bateram, recebi uma oferta para trabalhar numa empresa chamada Marplan. O salário da Marplan era algo que eu nem sabia que existia, de tão alto... Hoje não me assustaria, mas para quem tinha saído de ser estudante, e era pago por hora de aula, era fantástico. De toda forma, não aceitei. Achei que se eu entrasse na Marplan iria virar um businessman, não sairia nunca mais, porque seria muito sedutor ficar ali ganhando dinheiro.

Enquanto dava o curso na Fundação, também trabalhei de graça na $\mathrm{Fa}$ culdade Nacional de Filosofia, substituindo um professor chamado Hildebrando Leal, numa das matérias de sociologia. ${ }^{7}$ Ensinei estratificação social, e tive um senhor grupo de alunas, que depois viraram referências em suas áreas: Helena Lewin, Eli Diniz, Aspásia Camargo, Sônia Camargo... Na época surgiu ainda a oportunidade de um concurso para bolsas no recém-criado Instituto de Ciências Sociais da Universidade do Brasil, que ficava na rua Marquês de Olinda, em Botafogo. ${ }^{8}$ Me lembro de algumas pessoas que trabalharam lá: Luciano Martins, Maurício Vinhas de Queiroz... Era uma bolsa muito melhor, e fiz um projeto ambicioso, de um grupo grande de pesquisa, para trabalhar com eleições e partidos, mas o projeto foi rejeitado. Uma coisa interessante é que várias pessoas saíram da reunião dizendo: "Lutei pelo teu projeto, mas não deu". Pensei: "Espera aí, se são sete lá dentro e quatro estão dizendo que aprovaram, tem algo errado nessa 
conta...” Perdi a virgindade muitas vezes, e essa foi mais uma... Há sempre um jogo político, e as pessoas têm um compromisso relativo com a verdade, como parte desse jogo. $\mathrm{E}$ isso inclui o mundo acadêmico.

Continuei, então, dando aulas na PUC, escrevendo meus artigos, e decidi que tinha que sair de casa: afinal de contas eu tinha feito 28 anos e estava na hora. Estava aqui um professor visitante do Centro Latino-Americano de Pesquisas em Ciência Sociais, o Clapecso, então dirigido pelo Costa Pinto ou pelo Manuel Diegues Jr., chamado Joseph Kahl, que eu tinha visto numa reunião da American Sociological Association em Chicago, da qual participei como observador não-autorizado. Ele tinha um livro chamado The American class structure, li o livro, e quando cheguei aqui conversei com ele. $O$ fato de ter lido o livro e de tê-lo visto em Chicago talvez tenha tido alguma importância, porque ele me disse: "Olha, meu português é ruim. Estou pensando em fazer pesquisas, e você poderia me ajudar”. Acertamos então que iríamos rachar um apartamento, mas só Joseph Kahl seria capaz de dar a sugestão que deu. Ele morava num apartamento de uns três quartos na Nossa Senhora de Copacabana, e eu disse: "Ô Kahl, eu não posso pagar isso, não!" Ele: "Mas cada um paga de acordo com o seu salário profissional". Aprendi bastante com ele. Ele tinha uma pesquisa rolando, sobre modernização de valores, e prestei-lhe uma certa assessoria.

Um dia o Kahl chegou para mim e disse: "Gláucio, você devia voltar para os Estados Unidos para fazer o doutorado". Perguntei por quê, e ele disse: "Você sabe muito a respeito de sociologia política, bastante a respeito de estratificação, mas não sabe mais nada. A sociologia é muito mais rica do que isso". Pensei: "Quer saber, é verdade".

E você voltou então para os Estados Unidos, para fazer o doutorado.

Sim. Não obstante, antes de eu ir para os Estados Unidos, o Kahl me recomendou numa application que fiz para a Organização dos Estados Americanos, para ensinar no Museu Nacional de Antropologia e História do México, que dava um curso chamado Proyecto 104. Como a grana era boa e eu queria voltar ao México, onde tinha ido rapidamente como turista quando morava em Nova Orleans, me dispus a ir dar esse curso lá. Era coisa de quatro a seis meses, algo parecido. E certamente, apesar de não pagar muito bem para os padrões internacionais da época, o salário era muito mais do que eu jamais tinha recebido. Eu teria que dar um curso sobre método. Eu vivia querendo fugir do método, e as pessoas ficavam me convidando para dar cursos sobre método, porque ninguém sabia nada.

Fui para o México e mais uma vez tive um desses chance encounters: conheci minha primeira esposa, mãe de quatro filhos meus, Mireya. Conheci também Pablo Gonzalez Casanova. Ele me pediu para ler o livro dele, li a sério e fiz uma resenha. Entrei em contato com outras pessoas no México. Havia um padre 
que foi meu aluno e que depois escreveu um livro sobre métodos de pesquisa em ciências sociais. Mas essa turma não produziu tantas pessoas destacadas em ciências sociais quanto eu gostaria. Era um projeto semelhante a um mestrado, dentro de uma escola de antropologia, com pessoas vindas de toda a América Latina. Eram todos bolsistas, mas não tinham formação em ciências sociais. De toda forma a experiência também teve seu impacto, que foi o de reforçar meu interesse por questões latino-americanas. Esse interesse tinha começado bem antes, mas foi aí que o martelo bateu: "Isto aqui é parte de tua vida". Outra coisa importante foi o contato com a cultura indígena. A questão indígena no México, muito presente na obra de Pablo Gonzalez Casanova, também trouxe de volta a questão racial, que tinha sido despertada em Nova Orleans. Eu disse: "Vou estudar isso, quero conhecer melhor a questão racial e sua relação com a estratificação".

Afinal, do México fui para a Washington University em Saint Louis, Missouri, preparado para fazer um doutorado com base numa combinação de dados agregados e dados de survey. Eu estava interessado em explicar a votação radical. Primeiramente eu pretendia explicar tanto o voto dos radicais de direita - daí meu interesse lá em Chicago pela votação do Partido Nazista - quanto de esquerda, mas tive que afunilar e esquecer a direita, focar na esquerda. Eu já tinha publicado algo nesse sentido, tanto no livro que o Kahl editou, chamado La industrialización en América Latina, quanto em alguns boletins do Centro Latino-Americano de Pesquisas em Ciências Sociais. Eu me lembro que em um dos artigos usei análise fatorial, só que análise fatorial era feita na base da maquininha de calcular, e teoricamente levava-se seis meses para chegar a um resultado. Achei que dava muito trabalho, e também já estava entrando na minha cabeça a idéia de que existem dimensões que a gente não consegue medir diretamente, mas que podem, através de instrumentos estatísticos, ser aferidas com base em dados diretamente observados. Era ver o latente a partir do manifesto, uma estratégia analítica que me parecia muito relevante. Mas sei que teclei e teclei na Facit até gastar os dedos...

Normalmente, eu deveria ficar dois anos em Saint Louis. Resolvi então adotar uma estratégia arriscada, para não ficar lá simplesmente cumprindo tempo, que foi fazer os exames preliminares e de idiomas logo no primeiro ano. Fiz, me saí muito bem e pensei: "Pronto. Não vou ter que ficar aqui". Por que eu não queria ficar ali? Porque estava em correspondência com o Lipset, na Universidade da Califórnia, e queria ir para lá escrever a tese, que era muito mais na linha do Lipset do que na do Kahl. Aliás, Kahl não tinha nenhuma objeção a isso.

\section{Você foi para a Washington University em Saint Louis por causa do Foseph Kahl? \\ - Sim, ele era professor lá, foi meu orientador. No primeiro summer fomos para o México trabalhar na pesquisa dele lá. Essas experiências lati- no-americanas tiveram grande impacto e me forçaram a decidir, três anos mais tarde, ir para o Chile, e não para Harvard.}


O que foi que eu aprendi em Saint Louis? Tive um professor de psicologia social chamado Hamblin, e juntos escrevemos um artigo sobre as eleições do Allende, no Chile. Robert Hamblin era um psicólogo social, para mim o típico americano, mas um sujeito extremamente competente, que trabalhava com modelos experimentais e me mostrou que a forma das relações entre variáveis era importante, que nem tudo é "aumentou um pouquinho ali, aumenta um pouquinho aqui". Ele disse: "Não, há alguns fenômenos humanos que não são assim. Alguns são exponenciais, outros são decaying exponentials". Escrevemos um artigo no qual a idéia de que a resposta eleitoral era uma função-poder, power function, de uma série de variáveis que usávamos para prever, funcionava muito bem. Mandamos esse artigo sem muita esperança para a American Political Science Review, ele foi publicado sem mudanças, e passei a ser o primeiro latino-americano a publicar naquela revista.

Em Saint Louis, também fazia parte do meu comitê Alvin Gouldner. Gouldner é um sociólogo extremamente criativo, sabotado por uma personalidade egocentrada e hostil. Houve até um episódio hilário: quando cheguei à Washington University, vi um sujeito saindo de maca do Departamento de Sociologia, com a cara toda ensangüentada. Perguntei se tinha havido um acidente, e disseram: "No, Professor Gouldner punched him...” [Não, o Professor Gouldner deu-lhe um soco...] Estava lá também Irving Horowitz. Era um cara de esquerda, e minha relação com ele era por aí. Anos depois ele comprou uma revista, fundou um mini-império de publicações, ganhou muito dinheiro e abandonou a sociologia. Havia ainda outros professores em Saint Louis, com quem também aprendi

\section{Afinal, depois de Saint Louis você foi para a Califórnia trabalhar com Seymour} Lipset.

- Sim. Fui para Berkeley, Califórnia, para ensinar sociologia industrial e não sei mais o quê na graduação, e terminar o doutorado trabalhando no Insitute of International Studies. Passei três anos na Califórnia. Em menos de um ano terminei a tese, que se chamou Desenvolvimento econômico e radicalismo político, mandei para Saint Louis, mas perdi o prazo, porque ela tinha que ser impressa em um determinado papel. Só recebi o doutorado no ano seguinte, 1965.

\section{Você tinha o projeto de voltar logo para o Brasil?}

- Não pensava nisso, não. Eu estava publicando muito nos Estados Unidos, as oportunidades estavam aparecendo lá, e balancei, pesei. Durante minha permanência em Saint Louis publiquei uns quatro ou cinco artigos. A publicação mais prestigiosa foi essa que mencionei, na American Political Science Review, mas houve outras. Foi durante meu período na Califórnia que realmente publiquei mais. Eu vinha ao Brasil sempre que podia, tinha família no Rio, mantinha algum 
contato na PUC. O problema é que, no Rio de Janeiro, tanto a sociologia quanto a ciência política apareceram tarde. Havia um personalismo muito grande. Havia brigas homéricas entre Costa Pinto e Guerreiro Ramos, havia também o José Arthur Rios... Estava-se engatinhando, e ninguém sabia se queria fazer um programa mais sério ou menos sério. Mais sério significava também investir mais.

Você foi direto de Berkeley para o Chile? Por que você disse que não quis ir para Harvard? De onde vieram esses convites, e como você tomou sua decisão?

- Lipset foi para Harvard e queria me levar para lá como professor assistente. Foram três as razões que fizeram com que eu preferisse ir para o Chile. Primeiro, senti - e não foi a única vez - que ir para Harvard seria ficar permanentemente. Harvard é o centro do universo acadêmico americano, ia ser difícil sair de lá, e isso me incomodava. Segundo, eu me senti patronized. "Esse cara vem de um país em que não há ciência social e ciência política relevante, mas ele é uma exceção. The good Indian". Detestei isso. Uma terceira razão era que o Chile pagava mais e eu não pagaria impostos. Havia ainda uma quarta razão: o Chile é muito mais bonito fisicamente do que a área de Boston, apesar de culturalmente Boston ser um lugar extremamente gostoso.

Fui para o Chile em 1964, para dirigir a Escola de Sociologia da Faculdade Latino-Americana de Ciências Sociais, a Flacso. Fui como substituto, não ainda permanente, do Peter Heintz, que eu havia conhecido na Califórnia. A Flacso era uma instituição regional latino-americana, e uma das coisas interessantes e gostosas a respeito de Santiago do Chile é que havia lá 16 organizações regionais. Então havia muita interação, muita aprendizagem de um com o outro.

Quando você foi para o Chile, já tinha havido o golpe militar no Brasil?

- Já. Eu estava no Brasil quando houve o golpe.

E como foi a experiência na Flacso?

- A Flacso era uma instituição mínima para os padrões atuais, mas tinha uma organização como se fosse um órgão internacional. Foi colocada lá em grande parte pela Unesco. Nós éramos poucos: havia dois professores chilenos, Edmundo Fuenzalida e Eduardo Muñoz, que tinham mestrado, um cedido pela Suécia, Ingvar Ahman, que também tinha mestrado, e dois franceses. Assim que cheguei, começaram os conflitos com o secretário-geral. Primeiro, eu não era muito hábil. Segundo, nós estávamos numa instituição com cinco ou seis pessoas, e a primeira coisa que ele me diz é que "qualquer gasto aqui precisa de mi visto bueno". Pensei: quem é esse cara, de quem eu nunca ouvi falar? Como acontecia em toda América Latina, era alguém que tinha se formado em direito e foi colocado em uma Faculdade de Ciências Sociais. 
Eu não tinha um plano para a Flacso. Quando fui para lá, mal sabia o que era. Inclusive esse foi o erro de um dos dois advogados que eram professores lá, achar que eu tinha um plano, e que o meu plano era trasladar para a Flacso um departamento americano. É que ele não conseguia pensar uma instituição em que o diretor não tivesse um plano detalhado. Na América Latina de então, o pensamento era centralista e dirigista. Um diretor deveria ter um plano para impor aos alunos. Ora, não ter um plano não queria dizer que a coisa fosse correr ao léu. Mas significava que, em contraste com o Peter Heintz, que estava lá antes, eu não tinha uma teoria que fosse a minha e que eu quisesse implementar, tornar oficial, institucional. Ele tinha a dele, a teoria da tensão estrutural, quis fazer escola, e isso sempre me repugnou. Era dirigista demais.

A Flacso representou uma expansão muito grande do meu aprendizado sobre América Latina. Lá também descobri que os alunos aprendem muito conversando uns com os outros. Era evidente que os uruguaios não sabiam nada a respeito da Colômbia e vice-versa, como até hoje. Começou então a surgir a idéia, em um nível político- ideológico, de uma integração latino-americana. Mas aí começaram a bater os golpes militares, o que tornou tudo inviável. A tal ponto que discutíamos um mecanismo flexível para que as pessoas pudessem fugir de um país com seus cartões IBM. Esse era o grande problema: você sair com caixas de cartões IBM, levando sua pesquisa para outro país. Hoje você pega um pen-drive, põe no bolso e leva a sua biblioteca inteira. Naquele tempo não era assim.

Tive problemas políticos muito sérios quando era diretor da Flacso. A tradição era aceitar alunos fazendo entrevistas pessoais, e agreguei a isso alguns testes. Em dado momento fui à Argentina para entrevistar candidatos. Como isso era feito? Eu pedia a alguém da Universidade de Buenos Aires que organizasse as entrevistas. Mas na ocasião já tinha havido o golpe, e os milicos argentinos disseram: "Não, você não vai entrevistar ninguém da Universidade de Buenos Aires. Nós temos os nossos candidatos aqui". Eu disse: "Desculpe, mas não emplaca assim. Vou entrevistar, é meu direito. As bolsas são oferecidas pela Unesco, mas são distribuídas por nós, e eu não vou levar os que o senhor quer". Foi um negócio pesadíssimo, que me deu muita dor de cabeça com a Unesco. A Unesco é uma organização internacional, e os Estados-membros contavam. No caso da Flacso os Estados-membros teoricamente cooperavam com US\$ 150,00 por ano, o que não era nada, e a maioria nem pagava. Mas quando havia reunião para decidir se sim ou não, todo mundo se sentia dono do pedaço. Era uma situação um pouquinho difícil. Mas curti muito o Chile. Fiquei lá quatro anos, até 1968 , e nesse período formamos gente muito boa. O modelo que eu tinha era de estudos intensivos. E era preciso saber método. Eu ainda não havia acordado naquele momento para toda a extensão dos métodos qualitativos e de como eles podem ser úteis. Isso veio um pouquinho depois, quando comecei a conhecer o pessoal de análise de conteúdo no MIT. 
Em 1968 você voltou para o Brasil?

- Em 1968 Isaac Kerstenetzky me convidou para vir trabalhar no Brasil. Onde? Na Fundação Getulio Vargas. Embora minha vida fosse muito confortável no Chile - se não segurasse, eu ia virar um sibarita, ia consumir coisas estranhíssimas, simplesmente porque era fácil e barato -, eu estava um pouco chateado porque não conseguia escrever um livro. Escrevia artigo que não acabava mais, mas queria escrever um livro. Decidi então voltar com o convite do Isaac. Saí no dia 12 de dezembro de 1968 e cheguei aqui no dia do AI-5. Era um vôo da Varig que fazia Santiago, Assunção, Brasília e Rio. Desci em Brasília e naquela movimentação do aeroporto vi Vítor Nunes Leal, então ministro do Supremo Tribunal, que tinha sido cassado, mas eu não sabia. Lá fui eu falar com ele: "Vítor, você precisa fazer uma segunda edição revista do Coronelismo..." Todo mundo me olhando como se eu fosse um ET. E eu era um ET, nem estava sabendo do que estava acontecendo. Volto para o avião, sento, eles distribuem um jornal local, abro e vejo: AI-5. Disse: "Êta má sorte!" Chego ao Rio, telefono para o Isaac, e ele diz: "Gláucio, não dá". Não era porque eu fosse de esquerda ou de direita, nunca fui um cara reconhecido como esquerda, mas é que eu era sociólogo, e isso não podia. E aí, estou eu com mulher, um filho, como é que eu faço?

Fui ao CNPq e me encontrei com o diretor da parte de ciências sociais, um ex-aluno meu chamado Ivan Gonçalves de Souza. Nesse momento estava ali um militar conversando com ele, e o Ivan disse assim: "Ô Azevedo, você não queria alguém produtivo? Esse aqui eu garanto". Era o capitão-de-mar-e-guerra José Carlos Azevedo, então vice-reitor da UnB, que me convidou para ir a Brasília. Naquela época, fazia oito anos que Brasília tinha sido inaugurada. Estava tudo incompleto, a UnB era vermelha de pó, quando havia chuva inundava tudo... Fui ao Departamento de Sociologia e vi que estava cheio de pessoas sem mestrado, que tinham sido colocadas lá por indicação de cima - havia também um grupo mais moderno, muitos de Minas, que tinha mestrado. Pensei: "Isto aqui não é sério...”

Num dos meus telefonemas buscando emprego, Joe Kahl, que continuava em Saint Louis, disse: "Você deu sorte. Um visitante que vinha para cá não veio, e a vaga está aberta". Lá fui eu de volta para Saint Louis. Um ano depois, colocou-se outra vez a questão de para onde é que eu ia. Tornei a conversar com o Azevedo, e ele me ofereceu mais um salário para pagar os gastos de transporte. Só que o meu salário na UnB seria um quarto do salário que eu recebia em Saint Louis, um oitavo do que eu receberia no Chile. Como na época eu estava casado, e minha mulher tinha o mestrado em antropologia no México, eles fizeram um pacote: ela e eu. Aí comecei a era Brasília. 
Foi então que você foi para a UnB.

- Sim. Minha missão, por assim dizer, era buscar gente boa para construir um instituto lá. E os meus adversários não foram os caras sem pós-graduação que tinham sido colocados por indicação política. Foram os mais jovens, com mestrado, porque eles se sentiam os donos do pedaço. De repente chega um cara com $\mathrm{PhD}$, publicações... Comparativamente, eles ainda tinham muito terreno pela frente para chegar onde eu estava. Eu não me entendia muito bem com eles. Escrevi para um número grande - para época - de pessoas que já tinham doutorado, preferivelmente fora - em 1969, 70, não havia doutorado em ciência política no Brasil -, mas só um acabou indo: Hélcio Saraiva.

Fizemos então o mestrado, e aí houve um choque de concepções. Eu queria um mestrado extremamente qualificado, como tinha colaborado para fazer na Flacso, e não um mestradinho. Outros não pensavam assim. Pensavam que a Universidade de Brasília tinha que ser voltada do Centro para o Centro-Oeste, Norte, e talvez Nordeste, e que se se fizesse exames de seleção muito duros não viria muita gente. Eu não estava muito interessado nisso. Estava interessado em que do mestrado saíssem pessoas muito boas. Eles queriam que se aprovassem 40, e eu aprovava quatro, cinco ou oito. Havia um pouco de tensão, porque o meu requisito de qualidade se chocava com os planos da universidade de servir a três regiões.

O Instituto de Ciências Sociais da UnB incluía sociologia, política e antropologia. Aproveitei e fui coletando informações a respeito da ditadura. Eu tinha um compromisso verbal rapidíssimo com o Azevedo, que me disse o seguinte: "Você não se mete na pesada e nem dá apoio logístico a militante; em troca, se rolar problema, eu seguro a sua barra por 72 horas, até você sair do país". Isso não foi um acordo escrito, foi falado. Eu disse a ele: "Você sabe que eu não gosto de militares, não é? Você sabe que eu tenho uma experiência latino-americana ruim..." Ele disse: "Só não mexa com os militares daqui. Dos cucarachas você pode dizer o que quiser". Azevedo tinha um projeto modernizante. Eu não me lembrava dele, mas ele tinha me conhecido quando fui professor visitante no MIT por um semestre, no tempo em que estava na Flacso. Talvez isso o tenha influenciado.

\section{O que você pesquisou nesse tempo que passou na UnB?}

- Eu estava fazendo o livro que depois se chamou Sociedade e política no Brasil. O primeiro título foi $A$ democracia que passou, mas Juarez Brandão Lopes achou que era saudosista e mudei. O livro saiu em $1973 .{ }^{\circ}$ Nele aproveitei coisas que tinha feito antes e fiz algumas análises novas. Usei resultados de análises que fiz no computador da Washington University em Saint Louis, porque o computador da UnB tinha uma memória ridícula. Você colocava lá 40 observações e 2 variáveis, e ia para casa dormir, esperando a regressão no dia seguinte. 
Na preparação do livro, você tinha uma equipe, os alunos ajudavam?

- Tinha alunos excelentes, mas eles não ajudavam. Não tinha equipe, não tinha auxiliar, não tinha nada. Trabalhava sozinho, como aliás fiz a maior parte do tempo até hoje. Usei trabalhos de dois alunos, com o consentimento deles. Uma análise de um trabalho que escrevi em co-autoria com Nadya Araújo sobre a votação de um candidato comunista no estado de Goiás, e os dados da tese de mestrado do Celson José da Silva, que depois foi estudar filosofia na Alemanha e terminou sendo diretor da Faculdade de Filosofia da UFMG. Nadya é hoje professora do Departamento de Sociologia da USP. Só que Nadya, no último semestre, ficou um pouco cansada da minha orientação e da coisa empírica, se encantou com a Bárbara Freitag, uma pessoa fascinante, e foi fazer o mestrado com ela. Depois fez o doutorado no México.

Uma coisa interessante na UnB foi pegar alguns alunos que tinham sido reprovados no exame de mestrado, fazer um pequeno programa intensivo com eles, e depois um outro programa de mestrado. Todos emplacaram. Quem eram? O que saiu na frente de todo mundo era um que quase foi jubilado: Marcos Coimbra, hoje diretor da Vox Populi. Ele me foi indicado pelo Sérgio Abranches, que era meu orientando. Chamei-o, perguntei se ele queria trabalhar comigo, e dei-lhe um monte de coisas para ler, entre elas o Political man do Lipset: "Volta daqui a tanto tempo com isso lido". Ele voltou na metade do tempo com aquilo não só lido, mas comentado, e disparou. Estavam também no grupo de elite a Ana Maria Fernandes e a Fernanda Sobral, hoje professoras da UnB, Regina, que foi para Paris e depois para o Ceará... Enfim, esse grupo deu certíssimo, e isso me convenceu de que muitos alunos são reprovados porque ninguém tem interesse, ninguém ajuda, ninguém pega pela mão. Por falta de orientação. É uma coisa em que até hoje acredito firmemente. Antes eu dizia que o orientador não pode melhorar muito o aluno, mas pode acabar com ele. Hoje acredito que se pode melhorar e muito o aluno. O que não pode é orientação à distância, tipo "aparece no fim do semestre".

O periodo pós-64 marcou o início de novas pesquisas sobre a política brasileira. Seu livro Sociedade e política no Brasil, de 1973, foi, aliás, um dos primeiros trabalhos a analisar a mudança que estava ocorrendo na sociedade brasileira, e a explicar o golpe de 64 em função dessa mudança. A partir daí surgiram várias pesquisas, sobre partidos, eleições...

- Sobre o Legislativo, também. Escrevi um artigo com Sérgio Abranches chamado "As funções do Legislativo", ${ }^{10}$ que deu um bololô desgraçado, porque essencialmente nós mostrávamos que o Legislativo havia se suicidado. Ele derrotava as iniciativas originadas nele próprio, independentemente do partido. Partido não fazia diferença nenhuma. Naquela época eram dois, 
MDB e Arena, e, independentemente de quem apresentasse o projeto, a chance de ele ser aprovado era de bem menos de $10 \%$. Enquanto isso, quase $100 \%$ dos projetos de iniciativa do Executivo eram aprovados.

Nessa época também trabalhei com a questão da desigualdade na representação. Mostrei como as mudanças na legislação afetavam a desigualdade na representação dos estados, que já era grande e prejudicava sobretudo os estados mais populosos. Aí eu disse: "Mas isso tem uma correlata que é ideológica. Os partidos beneficiados são os de direita, e os prejudicados são os de esquerda". Esse artigo se chamou "Desigualdades eleitorais no Brasil" 11 e foi publicado na Revista de Ciência Política da Fundação com uma nota do editor. Como toda revista, a Revista de Ciência Política dizia algo como "os artigos são de responsabilidade dos autores". O meu tinha isso escrito embaixo outra vez. Ou seja, havia uma advertência dupla, genérica e específica. $\mathrm{O}$ que eu estava dizendo demais ali? Eram numerinhos...

Quando você quis publicar o Sociedade e política no Brasil, foi fácil encontrar uma editora? Houve problemas políticos?

- Quando acabei, mandei o livro para pessoas conhecidas: Juarez, que tinha assistido à minha defesa de tese na Washington University, Fernando Henrique, que eu tinha conhecido em São Paulo quando era presidente do centro acadêmico e depois reencontrei no Chile, e outros. Foi Fernando Henrique quem disse que eu devia publicar pela Difel. Juarez veio com a crítica de que o título não estava bom, e então botei um título mais neutro, tão descritivo quanto possível.

Sociedade e política no Brasil, ao sair, causou certo impacto na academia. Era uma primeira sistematização do processo eleitoral no Brasil durante um longo período.

- Era sociologia política.

E aí veio o livro da Maria do Carmo Campello de Souza, Estado e partidos políticos no Brasil, em 1976. ${ }^{12}$ Enquanto você estudava partidos e eleições, ela estudava partidos e governo.

- Sim. Antes de ler, encontrei com Simon Schwartzman, e ele disse: "É contra a gente!" Simon também me criticava muito por ser pela sociologia política. Ele tendia a privilegiar o político na explicação do político. Àquela altura já tinha publicado São Paulo e o Estado Nacional, com a história das coalizões entre o Sul e Minas contra São Paulo. ${ }^{13} \mathrm{O}$ que a Maria do Carmo dizia era: "Olha, vocês esqueceram os partidos. Tem partido aî". E a verdade é que nós esquecemos os partidos, sim. Mas ela não escreveu isso num sentido hostil, simplesmente afirmou isso, e era verdade. 
Nessa mesma época, anos 1970, você teve uma polêmica com Olavo Brasil de Lima Fr. Como foi isso?

- Foi justamente por causa do Sociedade e política no Brasil, quando vim para o Iuperj como professor visitante. O que eu me lembro é que Olavo achava que eu estava trabalhando partidos políticos em nível nacional e que os partidos políticos tinham, sobretudo, uma realidade estadual. Se ele tivesse dito que os partidos políticos também têm uma realidade estadual que pesa, nós íamos estar no mesmo barco, mas ele fez aquilo já em tom polêmico. Mas vejam: Olavo e eu começamos essa polêmica e saíamos sempre para almoçar. E planejamos dar um curso juntos exatamente por isso, porque nos pareceu que seria uma excelente oportunidade de usar nossa discórdia como exemplo de como se pode trabalhar bem: você discorda, mas é amigo. A polêmica ficou conhecida, mas o lado desconhecido dessa história é que Olavo e eu conversávamos e dávamos um curso juntos.

Olhando on retrospect, Sociedade política no Brasil ignora mesmo os estados, leva muito pouco em consideração a organização partidária dentro deles. Ou seja, meu marco era nacional, ignorando a importância dos estados, e o marco do Olavo era estadual, reduzindo o nacional à somatória ponderada dos estados. Acho que nós dois estávamos errados. Certamente, a partir do momento em que considerei os estados não só como um parâmetro espacial, mas também como algo que sobredetermina a organização partidária, o que eu fazia começou a ficar melhor.

Como disse há pouco, quem foi muito crítico com o Sociedade e política no Brasil foi o próprio Simon, mas pessoalmente, verbalmente. Mandei o livro para o Antônio Otavio Cintra, que é um fantástico crítico, para o Simon e para mais alguém para que fizessem comentários, e o do Simon foi que se devia explicar o político muito mais pelo político. "Pára com esse negócio de urbanização, industrialização, classe.” Acho que Simon estava negando o passado marxista dele, uma negação que começou na Flacso, porque por um tempo ele se entusiasmou com a perspectiva do Peter Heintz. O problema com o Olavo foi o detalhe de que a unidade de análise não devia ser aquela, enquanto Simon dizia que o enfoque estava errado. Não podia ser sociologia política e afirmar que era ciência política.

Depois de publicar Sociedade e política no Brasil, nos livros seguintes você transitou por outros temas, não é?

- Sim. Depois veio uma etapa agrária. Escrevi um livro chamado A questão agrária na América Latina, que publiquei em $1976 .{ }^{14}$ A América Latina pesou, e fui para Cornell, nos Estados Unidos, porque não havia absolutamente nada no Brasil para ler sobre a questão agrária na América Latina. Nossas bibliotecas desconheciam a produção latino-americana. Considero Questão agrária talvez 
melhor que o anterior, mas não causou nem marola. Essa ida para Cornell, aliás, foi a minha primeira "fuga" da UnB. A barra pesada foi depois de 1977. Aí é que foi o conflito com o Azevedo. Não posso esquecer que nessa ocasião Bolívar Lamounier, Fábio Wanderley Reis e Hélgio Trindade me escreveram imediatamente, dizendo "olha, a gente consegue trabalho para você". Isso me tocou, vou morrer sem me esquecer.

O livro seguinte foi político, escrito a toque de caixa. Era a época das Diretas Já, achei que era preciso fazer uma coisa menos panfletária a respeito, e fiz. Só que a Editora Vozes demorou, e o livro saiu depois que a emenda foi derrotada. De início ia se chamar Diretas fá, mas depois de passado o momento, o título ficou vazio. Colocamos então um nome absolutamente unsexy: Colégio eleitoral, convenções partidárias e eleições diretas. ${ }^{15}$ Nesse livro entraram inclusive alguns artigos de jornal. Diga-se de passagem que quando eu estava em Brasília comecei a escrever para as seções de opinião de jornais, coisa que não fazia antes. É claro que na hora do livro você recauchuta os artigos, amplia, dá mais conteúdo.

\section{Qual é a sua visão dos estudos de ciência política no Brasil hoje?}

- Nós temos uma área que acho que está muito bem desenvolvida aqui, que é a dos estudos legislativos. Pode-se fazer queixa de que é quase tudo federal, há poucos estudos sobre os legislativos estaduais, quase nada sobre os municipais, pouco sobre interação, mas é uma área de estudos que tem um núcleo forte. Argelina Figueiredo, Fernando Limongi, Fabito - Fabiano dos Santos-, Jairo Nicolau, Leany Bastos, Pedro Neiva, que foi meu orientando, e alguns outros, todos já fizeram o mesmo tipo de análise, buscando votação, características mais quantitativas etc. Pedro trabalhou com o Senado, o que é raro, a maioria trabalha com a Câmara. Essa talvez seja a área mais fortalecida. Por outro lado, nós abandonamos os estudos eleitorais. Há pouquíssimos. Se você for atrás dos dados de duas décadas atrás, fim da ditadura inclusive, verá que havia muitos estudos eleitorais, mas não é o caso agora. Os estudos eleitorais são caros, e acho também que temos um problema seriíssimo de professores que não sabem analisar dados. Logo, não há pessoal para fazer isso.

Acho que a ciência política no Brasil, que não está tão ruim quanto a sociologia, tem desprezado método - e por método não quero dizer estatística. Se você me perguntar qual é o estudo que usa entrevistas bem-feitas dentro de um universo de entrevistados aleatoriamente selecionados, vou dizer: "Nenhum". Tem muita gente que acha que método qualitativo é simplesmente não ter números. Você chuta o que quiser, e é método qualitativo. Por um lado, o fato de muitas pessoas que sabem trabalhar estarem estudando o Legislativo chupa talentos dos estudos eleitorais. É possível também que os estudos sobre partidos tenham esva- 
ziado bastante. Certamente eu acho que da ditadura para cá eles esvaziaram. Ou seja, a Arena existia, o MDB também, a gente brincava que um era o "partido do sim" e o outro do "sim senhor", mas ambos existiam. Maria D'Alva trabalhou muito bem o MDB. ${ }^{16}$ Mas não conheço um estudo bem feito sobre a Arena.

Esse é um dos problemas. Acho que as pessoas, no afã de terem uma postura antiquantitativa, foram levadas a uma postura antimétodo, qualquer que seja ele. Isso para mim é particularmente verdadeiro na sociologia, onde o trabalho de muitos é uma imitação barata, incompleta, da boa antropologia. É má sociologia tentando ser boa antropologia sem conseguir. Os partidos não têm sido bem estudados, a relação entre os poderes não têm sido estudadas. Ao mesmo tempo, há áreas novas. $\mathrm{O}$ Estado cresceu muito, e há gente hoje estudando instituições, ministérios, departamentos etc. O que me dá pena é não ver esses tipos de estudos imersos no arcabouço teórico da sociologia das organizações. Deixaram a sociologia das organizações de fora do estudo das organizações.

Enfim, os estudos eleitorais dependem da disponibilidade dos resultados, e agora há uma nova rama. Por exemplo, estou escrevendo um artigo com Sônia Terron, geógrafa, sobre como o Bolsa Família mudou a distribuição geográfica dos votos dados ao Lula. Jairo Nicolau fez isso junto com um rapaz chamado Vitor Peixoto, ${ }^{17}$ e um grupo de economistas os criticou de uma maneira até um pouco deselegante. Escrevi um artigo de jornal em que digo que nas eleições de 2006 a votação de Lula se encaixa na teoria que vincula pobreza a voto pela esquerda, e ironizo dizendo que hoje Lula é mais forte nos grotões, que era exatamente o que acontecia com a Arena. Wanderley Guilherme dos Santos, sem citar meu artigo, disse que os grotões não são mais aqueles, deixaram de ser grotões... Deu a mensagem dele.

Você não acha que os institutos de pesquisa de opinião, que são empresas comerciais muitas vezes ligadas a jornais, a redes de comunicação, acabaram por atrair os cientistas politicos e por fazer um trabalho de divulgação de informações que antes só o cientista fazia?

- Sem dúvida, houve uma migração de pessoas qualificadas para essas empresas. Migração significa que alguém ganha e alguém perde. As instituições acadêmicas perderam e, além disso, não se reproduziram. Conversei sobre isso com Nelson do Vale Silva, que tem a mesma opinião. Nós não tivemos a preocupação de formar quadros que fossem gradualmente entrando no mercado desse tipo de análise, de tal maneira que agora que estamos nos aposentando, ou morrendo, pode-se criar um vazio. As instituições foram tomadas por um grupo que não é muito devoto da pesquisa empírica. Não formamos novos sociólogos e cientistas políticos em número suficiente para ocupar as posições que se abriram 
com uma representação alta de pessoas que pesquisam quantitativa, qualitativa ou historicamente.

Você não acha também que hoje o main stream da ciência política mudou muito no mundo?

- Mudou, claro. Mas não acho que no Brasil se esteja fazendo o que se faz no mundo. Estou fazendo uma pequena análise dos títulos dos artigos publicados nas principais revistas brasileiras. Para mim, tradicionalismo é escrever a respeito de quem, e não de quê. O que é artigo sobre quem? "O pensamento de Bourdieu", "Weber e não sei que lá". Quê: Legislativo. O objeto é essencialmente uma instituição, são relações etc. Essa é a diferença. E há uma diferença muito grande entre as revistas brasileiras e as principais revistas estrangeiras, no sentido de que nós temos muito mais quem e muito menos quê. É até mais que isso, se olharmos o que é indicado para os alunos lerem. Estou fazendo também um levantamento das bibliografias e das ementas dos cursos de pós-graduação em sociologia e ciência política que incluem doutorado, e vejo algumas coisas. Primeiro, o mundo se reduz a alguns países. É incrível que em 2008, com Índia e China explodindo na economia mundial, nós não tenhamos um artigo sobre Índia e China recomendado aos leitores. Falamos em teoria clássica. Teoria clássica de quem? Para quem? Evidentemente, o que é clássico para uns não é o que é clássico para outros. O que pensam os africanos? Temos zero referência. A América Latina não existe no que se ensina hoje em sociologia e ciência política na pós-graduação, como não existe a África, não existe a Ásia, não existe a Europa Oriental. Existem Estados Unidos, Canadá, Inglaterra, Alemanha e França, e um pouco Itália, Espanha e Portugal. Um pouquinho. O resto não existe. E quando digo não existe é porque não existe mesmo. Zero.

Que mundo é esse, onde a gente supõe que o que dominava o pensamento ocidental na segunda metade do século XIX e início do século XX é a única coisa que existe? O Brasil, por exemplo, é um país que tem uma dinâmica religiosa fascinante. Por que fascinante? Porque é um país onde as igrejas evangélicas estão explodindo - e igrejas diferentes; ainda é o maior país católico do mundo; há muito sincretismo religioso, e há uma coisa nova, que existe em números muito pequenos na Europa, que é o espiritismo. Há muito mais espiritismo aqui do que na França de Kardec. Mas quando você vê, quase tudo o que o pessoal lê é Weber, $A$ ética protestante e o espírito do capitalismo. Quando eu comparo a nossa bibliografia com a que está sendo usada nos outros países - estou fazendo isso com a Hungria, com o Centro de Treinamento de Pós-Graduação da Europa Oriental, onde a questão religiosa é importante-, vejo que ninguém está lendo Weber para descobrir o problema de um conflito que é meio étnico, meio religioso. Eles estão estudando os autores que estão pesquisando sobre o tema. Acho que nós praticamos 
uma sociologia e uma ciência política bastante arcaicas, e muito alienadas. Não se trata da temática relevante para o país. Quem está fazendo trabalho sobre Bolsa Família? São os economistas.

A ciência política hoje - e essa foi uma mudança no main stream - está muito próxima dos micromodelos e, portanto, da economia. Trabalha-se com modelos abstratos, mas não se pensa o país...

- Essa é a minha principal objeção. Em parte isso acontece porque o pesquisar, na maior parte do país, saiu da agenda da pós-graduação em sociologia e ciência política. Você tem pessoas incrustadas, não tem mais departamentos. Quando eu morava fora e queria saber o que estava rolando, o que estava sendo descoberto a respeito do país na área de política, ia ler as teses de mestrado do Iuperj e sempre encontrava, a cada ano, três ou quatro interessantes. Acabou. Se eu for a São Paulo, vou ler 15 teses sobre Bourdieu em sociologia, algo sobre a sociedade brasileira, algo sobre religião e algo sobre trabalho. Muito poucas. A minha bronca, que as pessoas às vezes acham erroneamente que é a favor da quantidade, é a favor da pesquisa, seja qualitativa, seja quantitativa, histórica, geográfica. Vejamos, por exemplo, a relações entre o Bolsa Família e a votação do Lula. Lula teve em 2002 e 2006 uma votação praticamente igual em percentagem, mas quando você olha isso no mapa são duas distribuições geográficas muito diferentes. A correlação entre 2002 e 2006 é baixa. O que explica a mudança? Lula antes tinha mosaico, agora tem regiões de apoio. Onde estão essas regiões novas do lulismo? Onde o Bolsa Família é mais forte. Isso é sociologia tradicional ou ciência política tradicional? Não é mesmo! Você pode fazer a mesma coisa com crime, mas se pesquisa muito pouco.

Vivemos de pagar tributos àqueles que definimos como clássicos. Há um artigo de um autor africano que diz "Whose classics?"- clássicos de quem, para quem? É um artigo muito importante. Por que os clássicos mexicanos só são clássicos no México, os peruanos só são clássicos no Peru e assim por diante? Por que sabemos tão pouco sobre países que são nossos vizinhos? Não há um trabalho em toda a pós-graduação de ciência política e sociologia que mencione o Paraguai. E nós temos muito que ver com o Paraguai, muito. Bolívia: acho que encontrei quatro trabalhos, em 11 anos de pós-graduação. A Bolívia "boliviana" não a bolivariana - aparece quatro vezes. Tenho um problema com a orientação da ciência política e da sociologia, no sentido de que ela abandona a pesquisa empírica de qualquer tipo, e no sentido de que ela abandona o Brasil. O bom sociólogo hoje é o cara que trucida alguns autores - Elias, Foucault, Bourdieu -, não é o cara que vai descobrir alguma coisa a respeito da violência, da violência doméstica, da influência do Bolsa Família sobre a eleição de Lula ou sobre a mortalidade. Isso não interessa. Essa é a reflexão que eu faço. Esquecemos do país em que 
vivemos, esquecemos do continente em que vivemos e da condição de terceiro-mundistas, que é o que somos. Podem não gostar, mas somos sim.

Seria importante também trabalhar com a política em nível de município, não é?

- Claro. E há ainda novas formações que não estavam aí 30 anos atrás. As regiões metropolitanas cresceram muito mais que as cidades. Temos que repensar esse espaço. Não dá mais para chegar e dizer: Rio de Janeiro. Que Rio de Janeiro? Outra coisa: o dinheiro do petróleo corrompeu a política municipal na costa. A costa do petróleo é a costa do crime: Macaé, Cabo Frio... A pacatíssima - no longer - Friburgo figura entre os 30 municípios mais violentos do Brasil. O orçamento de Macaé é o dobro do de Niterói, com um terço da população, e a cidade é muito ruim.

Nós não fizemos aqui uma história de vida completa com você porque estávamos querendo ver como você chegou aos partidos políticos. Isso foi visto. Mas hoje você está estudando sobretudo a violência, e muito bem. Cansou dos partidos?

- Não. Eu traí... Realmente me apaixonei pela violência, quando descobri que políticas públicas baixam o nível de violência, e senti que eu podia ser um instrumento nisso. Essa descoberta aconteceu essencialmente através de dois programas, durante o governo do Cristóvão Buarque no Distrito Federal. Nós reduzimos a taxa de mortalidade por 10 mil veículos à metade em quatro anos. Se você fizer as contas, vai dar mais ou menos mil vidas, mil pessoas que não morreram e teriam morrido se continuasse o mesmo nível de violência. $\mathrm{O}$ número de pessoas mortas por afogamento no Distrito Federal também baixou de 100 para 40. Não existe mar, mas existe lago, rio, e proporcionalmente as pessoas morrem muito mais em lago e rio, porque é água leve. No caso particular do Distrito Federal, uma parte considerável dos casos era traumatismo craniano seguido de afogamento. $\mathrm{O}$ pessoal pulava, batia com a cabeça em árvore ou pedra submersa, e já era. Para evitar isso, nós cercamos essas áreas. Verificamos quais eram os pontos - detesto usar a palavra, mas se não usar ninguém entende: os pontos negros - e pusemos gente ali. É uma coisa muito pedestre. Daí eu passei para homicídios. Estamos entrando nessa área. Sugeri a adoção de pica-paus, que são detectores portáteis de metal. Dobramos a apreensão de armas ilegais no Distrito Federal, chegamos a 1.500. E a pergunta que fazemos é: quantas pessoas essas armas iriam matar?

Você se envolveu de corpo e alma em Brasília e participou de políticas públicas que deram certo. O governo entendeu, pôs em prática essas políticas, e os resultados foram muito positivos. Você veio para o Rio, se envolveu de corpo e alma, e não aconteceu nada... O que é que tem em Brasília que no Rio não tem?

- No que concerne a homicídio, o Rio de Janeiro entra num tipo de estado brasileiro que é aquele do platô, em nível alto. O que é platô? De um ano para o 
outro o homicídio dificilmente aumenta ou diminui mais que $10 \%$ no total, em geral menos de $5 \%$, mas o nível de 40,50 ou 60 por 100 mil habitantes é um nível alto. Esse é um padrão. Outro padrão inteiramente diferente é o de São Paulo, que está em queda livre desde 1999. Então, na minha leitura, nós temos que estudar não só São Paulo, onde o êxito é evidente, mas temos que estudar também os estados que não dão certo. Por que não dão certo? Por que o homicídio está crescendo no Paraná? Por que estagnou num nível muito alto em Pernambuco? Porque começou a baixar Rio de Janeiro durante o governo do Marcello Alencar, e depois estagnou, subiu e desceu, subiu e desceu? Por que cresceu tanto em Minas nos governos anteriores ao do Aécio? O que se fez que não se fazia antes, ou o que se deixou de fazer do que se fazia antes? - afinal Minas era, no Sudeste, o estado delícia, o estado seguro, com uma baixa taxa de homicídio. Hoje a taxa é bem mais alta que a de São Paulo - agora começou a baixar. O que houve? Temos que estudar esses casos, porque é daí que vão sair os subsídios para políticas públicas que vão salvar vidas. Não vão sair da leitura de Foucault. Estamos falando de Foucault pra lá e Bourdieu pra cá, e ninguém sabe por que cresceu o homicídio em Minas. Isso é gente, é vida humana que está sendo eliminada... Nós, cientistas políticos e sociólogos, temos algum tipo de compromisso com o país em que vivemos e que paga os nossos salários? É demais exigir um compromisso nosso? Acho que não.

Em parte entrei nessa área da violência porque tive a sensação, talvez absolutamente ingênua, de que, em péssimo inglês, I could make a difference. O que não quer dizer que eu não queira fazer e não faça outras coisas. Se eu viver o bastante, quero fazer um livro integrado sobre a ditadura militar. Sabe quem sugeriu isso? Maria Celina, que está sentada aqui, e que uma vez em Gainesville disse que os livros que tínhamos feito sobre os militares eram livros de memória, ${ }^{18} \mathrm{e}$ seria bom fazer a história. Acho que agora temos subsídios para fazer, para juntar todos esses cacos esparsos de conhecimento que se tem, e tentar às vezes cimentar, às vezes extrapolar um pouquinho, generalizar. Não abandonei isso. Também não abandonei a questão acadêmica, no sentido de estar estudando o que se ensina e o que não se ensina em sociologia e ciência política. A Alacip, por exemplo, que é a Associação Latino-Americana de Ciência Política, tem um concurso para as melhores teses de doutorado, mas você só pode entrar se tiver uma tese que pesquise algo a respeito da América Latina. Se você escrever uma tese maravilhosa sobre Weber, não entra. Acho que em algumas áreas nós precisamos ter políticas semelhantes, porque senão não vamos nos conhecer. Não abandonei nenhuma dessas preocupações, mas sem dúvida o meu amor, hoje, é o combate ao crime à violência. 
1. Por iniciativa do Padre Fernando Ávila, em 1954 foi criado na PUC-Rio o Instituto de Estudos Políticos e Sociais, que passou a ministrar cursos em 1955. Esses cursos evoluíram para a Escola de Sociologia e Política, que foi autorizada a funcionar pelo Decreto $\mathrm{n}^{\circ} 49.320$, de 22 de novembro de 1960, e em dezembro seguinte formou sua primeira turma de graduação. A partir da reforma universitária de 1968, a Escola de Sociologia e Política tornou-se o Departamento de Sociologia e Política, integrado ao Centro de Ciências Sociais da PUC-Rio.

\section{A Escola de Sociologia e Política de} São Paulo foi criada em 1933 e foi a primeira em sua área a oferecer cursos de pós-graduação no país. Hoje é parte da Fundação Escola de Sociologia e Política de São Paulo.

3. Júlio Barbosa era professor de sociologia da Faculdade de Ciências Econômicas da UFMG.

4. Fernando Henrique Cardoso era desde janeiro de 1955 assistente de Florestan Fernandes, catedrático de sociologia da Faculdade de Filosofia, Ciências e Letras da USP. O Curso de Ciências Sociais da USP esteve associado em sua origem à missão francesa que colaborou na fundação da universidade em 1934.

5. O Instituto Universitário de Pesquisas do Rio de Janeiro foi criado em 1969 como um centro de pesquisa e pós-graduação em sociologia e ciência política da Universidade Cândido Mendes.

\section{Revista de Direito Público e Ciência} Política, Rio de Janeiro, 3(2): 258-70, jul.-dez. 1960.
7. A Faculdade Nacional de Filosofia da Universidade do Brasil, desde sua criação, em 1939, tinha um Curso de Ciências Sociais. Referindo-se à transformação dos cientistas sociais, de intelectuais em profissionais, ocorrida na década de 1950, Evaristo de Moraes Filho lembra o grupo de Florestan Fernandes na USP e diz: "Enquanto isso, na nossa Faculdade [Nacional] de Filosofia, o próprio professor de sociologia não era um profissional, por assim dizer, apesar de homem muito bom e amigo dos alunos, Hildebrando Leal”. Entrevista em www.cle.unicamp.br/ arquivoshistoricos/eevaristo.pdf, acesso em 25 de agosto de 2008.

8. Segundo Evaristo de Moraes Filho, o Instituto de Ciências Sociais nasceu de um projeto de Temístocles Cavalcanti datado de 1951. Foi aprovado pelo Conselho Universitário em 1958 e inaugurado em 26 de dezembro daquele ano, com o propósito de se dedicar exclusivamente à pesquisa social. De seu primeiro conselho diretor faziam parte Vítor Nunes Leal (presidente), Darcy Ribeiro, Temístocles Cavalcanti, L. A. Costa Pinto, Evaristo de Moraes Filho, Lineu de Albuquerque Melo e Luiz de Castro Faria. Esteve instalado na rua Marquês de Olinda de 1961 a 1968. Idem, ibidem.

9. Sociedade e política no Brasil (desenvolvimento, classe e política durante a Segunda República). São Paulo: Difel, 1973.

10. Publicado em Revista de Administração Pública, Rio de Janeiro 7(1): 73-98, jan.-mar. 1973.

11. Publicado em: Revista de Ciência Política, Rio de Janeiro 7(1): 25-48, jan.-mar. 1973. 
12. Estado e partidos políticos no Brasil. São Paulo: Alfa Ômega, 1976.

13. São Paulo e o Estado Nacional. São Paulo: Difel, 1975.

14. Rio de Janeiro: Zahar, 1976.

15. Petrópolis: Vozes, 1984.

16. Maria D'Alva Gil Kinzo, Oposição e autoritarismo: gênese e trajetória do $M D B$ (1966-1979). São Paulo: IDESP/Vértice, 1988.
17. As bases municipais da votação de Lula em 2006, in Cadernos do Fórum Nacional $\mathrm{n}^{0}$ 6, Rio de Janeiro, fevereiro de 2007.

18. Referência aos três volumes sobre a memória militar (Visões do golpe e Os anos de chumbo, de 1994, e $A$ volta aos quartéis, de 1995) organizados por Gláucio Ary Dillon Soares, Maria Celina D'Araujo e Celso Castro, publicados pela Relume-Dumará. 